\title{
Oral Inverted Ductal Papilloma: Report of a Case with Immunohistochemical Study
}

\author{
Apostolos Epivatianos ${ }^{1}$, Demetrios Antoniades ${ }^{2}$, Thomas Zaraboukas ${ }^{3}$ and Athanasios K. Poulopoulos ${ }^{*}, 4$ \\ ${ }^{I}$ Department of Oral Medicine and Oral Pathology, School of Dentistry, University of Thessaloniki, Greece \\ ${ }^{2}$ Department of Oral Medicine and Oral Pathology, School of Dentistry, University of Thessaloniki, Greece \\ ${ }^{3}$ Department of Histopathology, Medical School, University of Thessaloniki, Greece \\ ${ }^{4}$ Department of Oral Medicine and Oral Pathology, School of Dentistry, University of Thessaloniki, Greece
}

\begin{abstract}
Oral inverted ductal papilloma (IDP) is a very uncommon lesion of minor salivary gland origin. Forty five cases have been reported in the literature. We describe a case of IDP developed as an asymptomatic submucosal mass in the hard palate of a middle-aged woman. Excisional biopsy was performed, and ten months of patient's follow-up showed no evidence of recurrence. The major portion of the tumour was made up of proliferating configurations containing epidermoid cells. Some microcysts and crypts were seen. Immunohistochemical analysis of the present case supports the hypothesis that IDP arises from excretory duct cells.
\end{abstract}

Keywords: Oral inverted ductal papilloma, salivary glands, pathology, immunohistochemistry.

\section{INTRODUCTION}

The inverted papilloma (IP) is a common lesion of the nasal cavity, paranasal sinuses, urinary tract, cervix and lacrimal sac. IP of the nasal cavity and paranasal sinuses can recur after excision and may be associated with squamous cell carcinoma in 10\%-15\% of cases [1]. In 1982 White et al. described a similar tumour, inverted ductal papilloma(IDP) of minor salivary gland origin, showing endophytic papillary proliferation of epithelial cells but differing in growth pattern, constituent cells, and biological behavior [2]. In the World Health Organization (WHO) histological classification of salivary gland tumours, IDP is classified as a ductal papilloma along with intraductal papilloma and sialadenoma papilliferum [3].

IDP is very uncommon, forty-five cases have been reported in the literature. We describe a recent case of IDP developed in the hard palate of a middle-aged woman, the immunohistochemical findings and review the literature.

\section{REPORT OF A CASE}

A 53-year-old woman was referred in the Department of Oral Medicine and Oral Pathology because of an asymptomatic growth in the palate that had developed over 3 years. Clinical examination showed a circular submucosal mass with a papillary to wrinkled surface and diameter $0.6 \mathrm{~cm}$, located in the hard palate at the border with soft palate. The patient's dental and medical histories were unremarkable. The clinical provisional diagnosis was squamous papilloma. Under local anesthesia excisional biopsy was carried out. The wound was closed secondary, the healing was uneventful and follow-up showed no evidence of recurrence.

*Address correspondence to this author at the Department of Oral Medicine and Oral Pathology. School of Dentistry. University of Thessaloniki. Thessaloniki 54124. Greece; Tel: +302310-999528; Fax: +302310-999455;

E-mail: akpoul@yahoo.gr
The specimen was fixed in 10\% formalin and embedded in paraffin. Serial sections were cut at a thickness of $4 \mu \mathrm{m}$ and were stained with hematoxylin and eosin and for immunohistochemistry. Sections stained with hematoxylin and eosin showed a papillary endophytic epithelial mass that peripherally was separated from the mucosal epithelium by a thin band of connective tissue (Fig. 1A). The proliferating configurations contained epidermoid cells that their luminal surface was covered by a simple layer of cuboidal cells (Fig. 1B). In two areas the papillary projections formed microcysts lined by columnar and cuboidal cells. Interspersed among these cells mucous cells were occasionally present (Fig. 1C). Many crypts facing the lumen were also seen (Fig. 1A). Mitotic figures of tumour cells were infrequent. Histologic diagnosis of IDP was made based on these findings. In the mucosal epithelium koilocytes and binucleated keratinocytes were observed, findings compatible with viral infection (Fig. 2A,B).

Sections were evaluated immunohistochemically for the detection of Pan-cytokeratin, CAM 5.2 (cyto-keratins 8, 18) and cytokeratin 7 using the Streptavidin-biotin-complex method. Endogenous peroxidase was quenched in methanolic hydrogen peroxide $3 \%$ for $10 \mathrm{~min}$ at room temperature before blocking non-specific binding in the corresponding non-immune serum. Then the sections were pretreated for antigen retrieval and incubated with monoclonal primary antibodies (Table 1). Negative controls were carried out by substituting primary antibodies with non-immune serum of other species. The method was performed using the autostainer Ventana (Ventana Med Systems Inc. Tuscon, AZ, USA) and the reaction was developed using diaminobenzidine. Hematoxylin was used as counterstain. Pancytokeratin was positive in almost all tumour cells, CAM 5.2 in most luminal cells and cytokeratin 7 in all luminal and many subliminal cells (Fig. 3). The mucosal epithelium was positive for Pan-cytokeratin but negative for CAM 5.2 and cytokeratin 7 . 

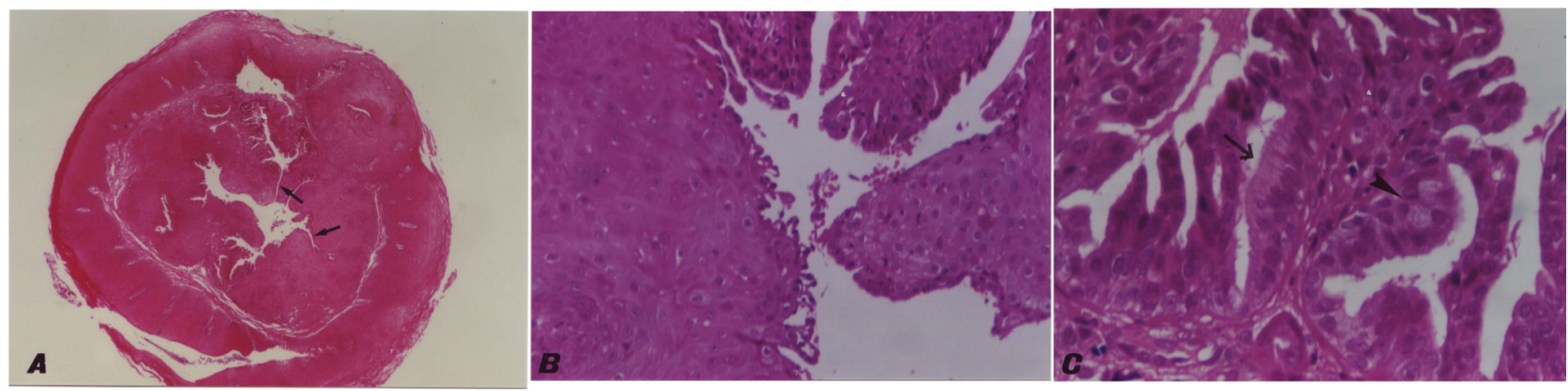

Fig. (1). (A) The tumour comprises a well demarcated mass of papillomatous projections filling a salivary duct. Cleft-like spaces are present as extensions of the central cystic space (hematoxylin and eosin; original magnification X25). (B) The tumour consists of epidermoid cells that in most luminal areas are covered by cuboidal cells (hematoxylin and eosin; original magnification X200). (C) Papillary projections form microcystic spaces and consist of cuboidal and columnar cells (arrowhead). Occasionally mucous cells are present (arrow) (hematoxylin and eosin; original magnification X400).
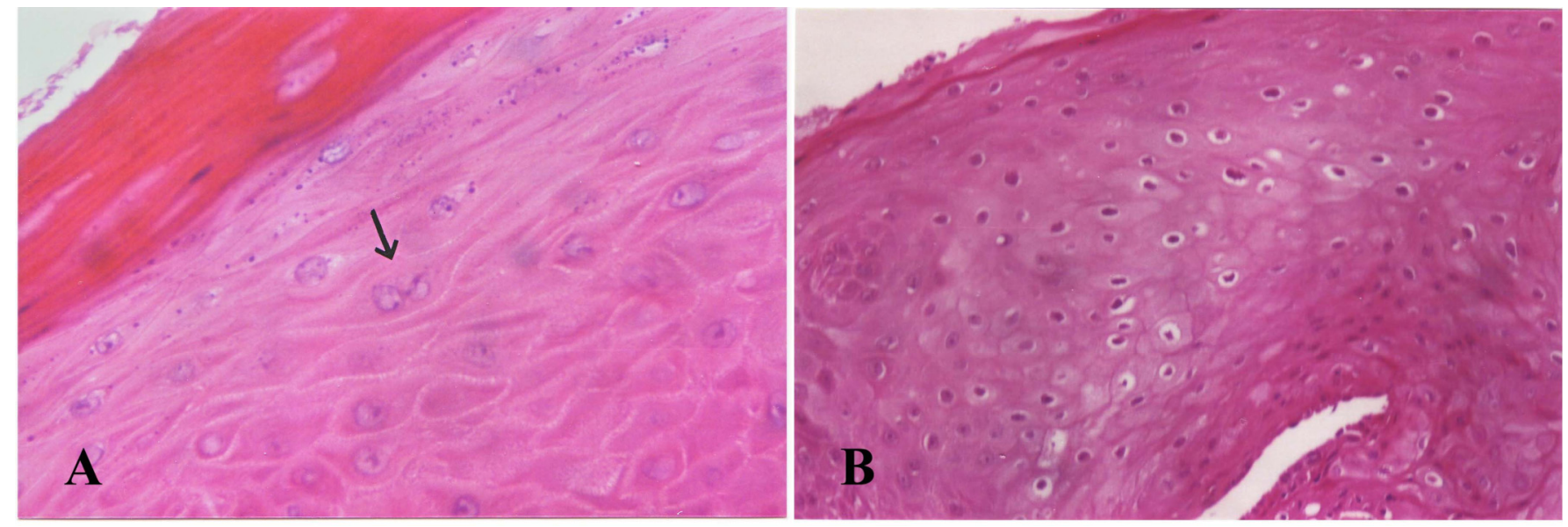

Fig. (2). (A,B) In the mucosal epithelium koilocytes and binucleated keratinocytes were observed, findings compatible with viral infection. (arrow). (hematoxylin and eosin; original magnification X400).

Table 1. Clone, Source and Pretreatment for Antigen retrieval, Dilutions and Incubation of Primary Antibodies

\begin{tabular}{|c|c|c|c|c|c|}
\hline Antibody & Source & Clone & Pretreatment & Dilution & Incubation \\
\hline $\begin{array}{c}\text { Pan-cytokeratin }(\mathrm{Cks} \\
1,2,3,4,5,6,7,8,10,14,15,16,19)\end{array}$ & $\begin{array}{c}\text { Zymed Lab. San Fracisco, } \\
\text { CA, USA }\end{array}$ & AE1/AE3 & $\begin{array}{c}\text { Protease I Sigma, St Louis, } \\
\text { MO, USA } \\
0.05 \% \text { in } 0.1 \mathrm{M} \text { phosphate } \\
\text { buffer, pH } 7.8 ; 95^{\circ} \mathrm{C} ; 15 \mathrm{~min}\end{array}$ & $1: 50$ & $30 \mathrm{~min}$ \\
\hline CAM $5.2(\mathrm{CKs} 8,18)$ & $\begin{array}{c}\text { Novocastra Lab. Newcastle } \\
\text { upon Tyne, UK }\end{array}$ & $5 \mathrm{D} 3$ & Protease & $1: 100$ & $30 \mathrm{~min}$ \\
\hline Cytokeratin 7 & $\begin{array}{c}\text { Biocare Carmino Diablo, CA, } \\
\text { USA }\end{array}$ & K 72.7 & Protease & $1: 80$ & $30 \mathrm{~min}$ \\
\hline
\end{tabular}
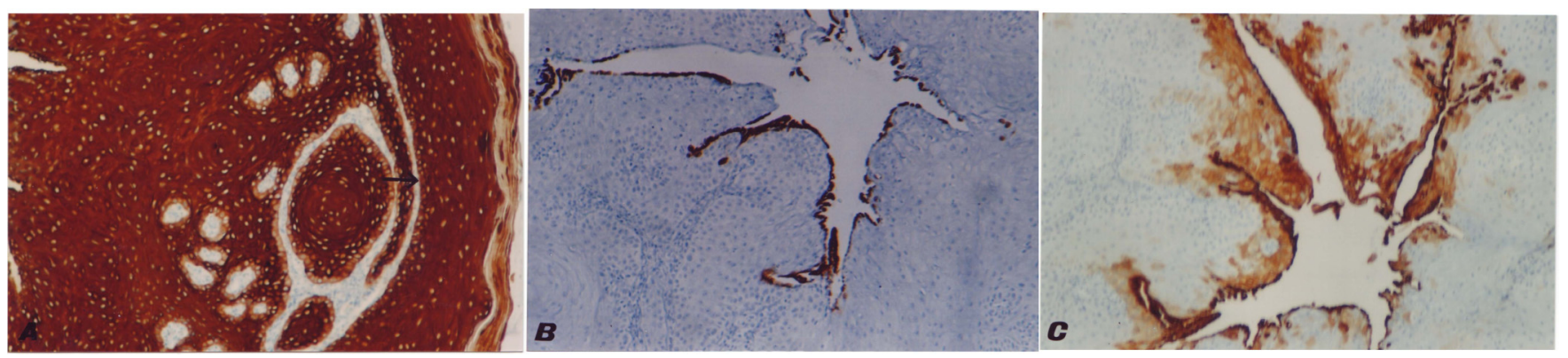

Fig. (3). (A) Pan-cytokeratin expression in mucosal epithelium (arrow) and almost all tumour cells. (Streptavidin-biotin-complex method; original magnification X100). (B) Most luminal tumour cells express CAM 5.2. (Streptavidin-biotin-complex method; original magnification X100). (C) Luminal and subluminal tumour cells express cytokeratin 7 (Streptavidin-biotin-complex method; original magnification X100). 


\section{DISCUSSION}

Our search in literature found 45 cases of IDP [2, 4-18]. The clinical features of these cases are summarized in Table 2. Analysis of the data shows that the most frequent locations of IDP are the lips (40\%) and buccal mucosa (31.4\%) followed by the palate $(14.2 \%)$, mandibular vestibule $(11.4 \%)$ and floor of the mouth $(2.9 \%)$. The tumour shows a small predilection for males (1.2:1). The ages of patients range from 22-77 years with a peak in the sixth (35.5\%) and seventh $(22.5 \%)$ decades and a mean age of 51 years. The size of tumour most often is $1.0-1.5 \mathrm{~cm}$ and ranges from $0.5-1.5 \mathrm{~cm}$. No cases of malignant transformation or recurrence have been reported.
Clinically IDP occurs as a firm, discrete submucosal mass beneath a normal mucosa and sometimes a small surface pore may be contiguous with the lumen of the underlying tumour $[4,8,10]$. Because of the clinical features of IDP its provisional diagnosis is mucocele [6, 14], lipoma, fibroma and salivary gland tumour $[2,8]$. In our case the provisional diagnosis was squamous papilloma because of the papillary to wrinkled surface of the lesion. Brannon et al. [14] reported 3 cases with wrinkled to papillary surface which provisionally were diagnosed as squamous papilloma. Diagnosis of IDP can be established only after histological examination.

Table 2. Clinical Features of Forty-Six Cases of Oral Inverted Ductal Papilloma

\begin{tabular}{|c|c|c|c|c|}
\hline Author & Age of Patients & Gender & Location & Size (cm) \\
\hline White et al. [2] & $\begin{array}{l}66 \\
54 \\
61 \\
52\end{array}$ & $\begin{array}{l}\mathrm{M} \\
\mathrm{F} \\
\mathrm{M} \\
\mathrm{F}\end{array}$ & $\begin{array}{l}\text { Floor of mouth } \\
\text { Mand. Vestib. } \\
\text { Mand Vestib } \\
\text { Soft palate. }\end{array}$ & $\begin{array}{l}1.5 \\
1.0 \\
1.0 \\
1.0\end{array}$ \\
\hline Wilson and Robinson [4] & 52 & $\mathrm{~F}$ & Buccal mucosa & 1.0 \\
\hline Regezi et al. [5] & $\begin{array}{l}- \\
- \\
- \\
-\end{array}$ & $\begin{array}{l}- \\
- \\
-\end{array}$ & $\begin{array}{c}\text { Upper lip } \\
\text { Lower lip } \\
\text { Lower lip } \\
\text { Buccal mucosa and gingiva }\end{array}$ & $\begin{array}{l}- \\
- \\
- \\
-\end{array}$ \\
\hline Clark et al. [6] & 44 & M & Lower lip & - \\
\hline Batsakis [7] & $\begin{array}{l}- \\
- \\
-\end{array}$ & $\begin{array}{l}\mathrm{M} \\
\mathrm{F} \\
\mathrm{F}\end{array}$ & $\begin{array}{c}\text { Lip-NOS } \\
\text { Buccal mucosa } \\
\text { Buccal mucosa }\end{array}$ & Range $1.0-1.5$ \\
\hline Franklin and Ong [8] & 36 & $\mathrm{~F}$ & Buccal mucosa & 1.5 \\
\hline Koutlas et al. [9] & 58 & M & Buccal mucosa & 1.2 \\
\hline Hegarty et al. [10] & 50 & - & Lower lip & 1.0 \\
\hline Machado de Sousa [11] & $\begin{array}{l}22 \\
51\end{array}$ & $\begin{array}{l}\mathrm{F} \\
\mathrm{M}\end{array}$ & $\begin{array}{c}\text { Palate } \\
\text { Buccal mucosa }\end{array}$ & - \\
\hline Ellis and Auclair [12] & $\begin{array}{c}4 \text { cases } \\
\text { Range } 32-66 \\
\text { Average } 50\end{array}$ & - & - & - \\
\hline Scolyer et al. [13] & 58 & $\mathrm{~F}$ & Buccal mucosa & 1.7 \\
\hline Brannon et al. [14] & $\begin{array}{c}65 \\
32 \\
64 \\
77 \\
- \\
29 \\
60 \\
45 \\
52 \\
67 \\
28 \\
60 \\
-\end{array}$ & $\begin{array}{l}\text { M } \\
\text { M } \\
\text { M } \\
\text { F } \\
\text { M } \\
\text { F } \\
\text { M } \\
\text { M } \\
\text { F } \\
\text { M } \\
\text { F } \\
\text { M } \\
\text { M }\end{array}$ & $\begin{array}{l}\text { Mand. Vestib } \\
\text { Soft palate } \\
\text { Lower lip } \\
\text { Buccal mucosa } \\
\text { Lower lip } \\
\text { Lip-NOS } \\
\text { Palate-NOS } \\
\text { Lower lip } \\
\text { Buccal mucosa } \\
\text { Buccal mucosa } \\
\text { Lower lip } \\
\text { Lower lip } \\
\text { Oral mucosa-NOS }\end{array}$ & $\begin{array}{c}\text { Range } 0.5-1.5 \\
\text { Average } 0.9\end{array}$ \\
\hline Haberland- Carrodeguas et al. [15] & $\begin{array}{c}6 \text { cases } \\
\text { Range } 27-57 \\
\text { Average } 43\end{array}$ & $\begin{array}{c}3 \mathrm{~F} \\
3 \mathrm{M}\end{array}$ & - & $\begin{array}{l}- \\
-\end{array}$ \\
\hline Cabov et al. [16] & 41 & M & Buccal mucosa & 1.5 \\
\hline Jurgens et al. [17] & 65 & $\mathrm{~F}$ & Lower lip & 1.5 \\
\hline Kubota et al. [18] & 49 & M & Buccal mucosa & 1.5 \\
\hline Present study & 53 & F & Hard palate & 0.6 \\
\hline
\end{tabular}


Our case met the histological criteria of IDP [3, 12]. IDP is characterized as a well-circumscribed submucosal mass that has an epidermoid appearance. Basaloid and squamous cells are arranged in thick, bulbous papillary proliferations that project in a luminal cavity. They appear to fill the luminal cavity and extend outwardly into the surrounding lamina propria. There are no features of infiltration that might be suggestive of malignancy. The lumen of the tumour is usually narrowed and branching thus forming clefts as a result of the proliferation of tumour cells in broad papillae into the luminal cavity. In some cases the lumen communicates by a narrow opening with the mucosal surface. The bulk of the tumour is composed of basaloid or epidermoid cells that protrude into the lumen and are covered by columnar and cuboidal cells. Interspersed among these ductal cells mucous cells may be present. Within the proliferated epithelium small microcysts are present.

IDP should be histologically differentiated from intraductal papilloma [10, 13], sialadenoma papilliferum [10, 13], mucoepidermoid carcinoma $[7,13]$ and the rare inverted oral papilloma [10]. In intraductal papilloma the lumen is partially filled with many branching papillary elements consisting of fibrovascular cores surfaced by columnar epithelium whereas in IDP the bulbous proliferations are composed of epidermoid cells that expand or push into the surrounding stroma [14]. Sialadenoma papilliferum consists of the exophytic papillomatous component that is covered by parakeratotic and acanthotic squamous epithelium and the underlying component that consists of a proliferation of ducts that form tortuous clefts, channels and cystic spaces. The ducts are lined by a mixture of pseudostratified columnar and bilayered epithelium with columnar and cuboidal basal cells [19]. In IDP lack the multicystic and/or multinodular and infiltrative growth pattern that are present in mucoepidermoid carcinoma [20]. So-called oral inverted papilloma [21] is arisen from surface epithelium and characterized by downward growths of squamous epithelium [20].

The origin of IDP is unclear. Eversole [22] and Batsakis [23] have postulated that IDP arises from excretory duct reserve cell whereas other authors $[8,11,14]$ from excretory duct cells. Hegarty et al. [10] and Kubota et al. [18] reported that is not clear which of the aforementioned two theories is correct but whichever is correct, IDP appears to result of a process of proliferation and suamous metaplasia of a minor salivary gland excretory duct. Our immunohistochemical results are in agreement with previous studies $[9,11,18]$. The similar expression of Pan-cytokeratin in epidermoid tumour cells and mucosal epithelium suggest a similar immunoprofile, whereas the expression of cytokeratin 7 and 18 in cuboidal and columnar luminal cells of IDP, observed in the current and previous studies $[11,18]$, supports evidence of luminal excretory duct cells [24]. The basal cells of striated and excretory ducts play the central role for a pluridirectional morphogenetic differentiation in the majority of ductal metaplasia [24] and therefore appears likely to be the progenitor cells of the proliferated and metaplastic squamous cells in IDP.

In the current study the present of koilocytes and binucleated keratinocytes in the mucosal surface epithelium of the lesion is compatible with viral infection, although there was not any molecular investigations to confirm the presence of HPV. Haberland-Carrodeguas et al. [15] investigated 6 cases of IDP for human papillomavirus (HPV) DNA and found 5 cases that showed histological features of HPV infection in the surface epithelium consistent with koilocytosis, binucleated keratinocytes and papillomatosis, whereas 4 out of 5 these cases had features of HPV infection in the endophytic component of the tumour. Three of these five cases were positive for HPV subtypes 6/11. In contrast, two case reports $[8,13]$ failed to detect HPV DNA. The exact role of HPV in the aetiology and pathogenesis of IDP is equivocal. According to data compiled by Syrjanen and Syrjanen [25] the prevalence of HPV in normal oral mucosa is approximately $11 \%$ and therefore there is a potential for the incidental identification of the virus in an otherwise unrelated pathological process [15].

\section{REFERENCES}

[1] Hyams VJ. Papilloma of the nasal cavity and paranasal sinuses: a clinicopathological study of 315 cases. Ann Otol Rhinol Laryngol 1971; 80: 192-06.

[2] White DK, Miller AS, McDaniel RK, et al. Inverted ductal papilloma: a distinct lesion of minor salivary gland. Cancer 1982; 49: 519-24.

[3] Brannon RB, Sciubba JJ. Ductal papillomas. In Barnes L, Eveson JW, Reichart P, Sidransky D Eds. World Health Organization Classification of Tumours. Pathology and Genetics of Tumours of the Head and Neck. Lyon, IARC Press, 2005, p 270.

[4] Wilson DF, Robinson BW. Oral inverted ductal papilloma. Oral Surg Oral Med Oral Pathol 1984; 57: 520-23.

[5] Regezi JA, Loyd RV, Zarbo RJ, et al. Minor salivary gland tumors. Cancer 1985; 55: 108-15.

[6] Clark DB, Priddy RW, Swanson AE. Oral inverted ductal papilloma. Oral Surg Oral Med Oral Pathol 1990; 69: 487-90.

[7] Batsakis JG. Oral monomorphic adenomas. Ann Otol Rhinol Laryngol 1991; 100: 348-50.

[8] Franklin CD, Ong TK. Ductal papilloma of the minor salivary gland. Histopathology 1991; 19: 180-2.

[9] Koutlas IG, Jessurum J, Iamaroon A. Immunohistochemical evaluation and in situ hybridization in a case of oral inverted ductal papilloma. J Oral Maxillofac Surg 1994 ; 52: 503-06.

[10] Hegarty DJ, Hopper C, Speight PM. Inverted ductal papilloma of minor salivary glands. J Oral Pathol Med 1994; 23: 334-6.

[11] de Sousa SO, Sesso A, Araujo NS, et al. Inverted ductal papilloma of minor salivary gland origin. Morphological aspects and cytokeratin expression. Eur Arch Otorhinolaryngol 1995; 252: 370-3.

[12] Ellis GL, Auclair PL. Tumors of the Salivary Glands. Atlas of Tumor Pathology. $3^{\text {rd }}$ series, Fascicle 17. Washington DC, Armed Forces Institute of Pathology, 1996, p 120.

[13] Scolyer RA, Rose B, Painter DM. Test and teach. Number 96:part 1. Inverted duct papilloma of minor salivary gland origin. Pathology 1999; 31: 372, 423-4.

[14] Brannon RB, Sciubba JJ, Grulani M. Ductal papillomas of salivary gland origin. A report of 19 cases and a review of the literature. Oral Surg Oral Med Oral Pathol Oral Radiol Endod 2001; 92: 6877.

[15] Haberland- Carrodeguas C, Fornatora ML, Reich RF, et al. Detection of human papillomavirus DNA in oral inverted papillomas. $\mathrm{J}$ Clin Pathol 2003; 56: 910-13.

[16] Cabov T, Macan D, Manajlovic S, et al. Oral inverted ductal papilloma. Brit J Oral Maxillofac Surg 2004; 42: 75-77.

[17] Jurgens PE. Inverted ductal papilloma of the lower lip: a case report. J Oral Maxillofac Surg 2004 ; 62: 1158-61.

[18] Kubota N, Suzuki K, Kawai Y, et al. Inverted ductal papilloma of minor salivary gland: Case report with immunohistochemical study and literature review. Pathol Int 2006; 56: 457-61.

[19] Dardick I. Color Atlas/Text of salivary Gland Tumor Pathology. New York, Tokyo, Igaku-Shoin, 1996, p 129.

[20] Ellis GL, Auclair PL. Ductal papillomas. In : Surgical Pathology of Salivary Glands. Ellis Gl, AuclairPL, Gnepp DR Eds. Philadelphia, Saunders, 1991, p 238.

[21] Greer RO. Inverted oral papilloma. Oral Surg Oral Med Oral Pathol 1973; 36: 400-03. 
[22] Eversole LR. Histogenic classification of salivary tumors. Arch Pathol 1971; 92: 433-43.

[23] Batsakis JG. Salivary gland neoplasia-an outcome of modified morphogenesis and cytodifferentiation. Oral Surg 1980; 40: 229232.
[24] Ihrler S, Zietz C, Sendelhofert A, et al. A morphogenetic concept of salivary duct regeneration and metaplasia. Virchows Arch 2002; 440: 519-26.

[25] Syrjanen K, Syrjanen S. HPV infection of the oral mucosa. Papillomavirus infections in human pathology. Chichester, John Wiley\&Sons, 2000, p 380. 